\title{
Market Basket Analysis pada Barang Minimarket dimasa Pandemi Covid-19
}

\author{
Sasa Ani Arnomo ${ }^{\text {al }}$ \\ ${ }^{a}$ Program Studi Sistem Informasi, Universitas Putera Batam \\ Jl. R. Soeprapto, Tembesi, Batam, Kepulauan Riau, Indonesia \\ ${ }^{1}$ sasa@puterabatam.ac.id
}

\begin{abstract}
Abstrak
Sebuah minimarket memerlukan suatu analisa untuk mengetahui kebiasaan pembelian konsumen di masa pandemi covid 19. Penelitian ini nantinya akan berguna untuk menata tata letak barang di toko, menentukan promosi produk dan mengefisienkan stok produk agar transaksi penjualan berjalan lancar serta meningkatkan hasil penjualan. Metode market basket analys dapat digunakan untuk menganalisis keterkaitan produk yang dibeli konsumen sekaligus untuk mengetahui kebiasaan membeli konsumen. Penelitian berhasil menemukan kombinasi produk yang saling terkait yang memiliki nilai support dan confidence tertinggi pada kombinasi produk Basic Food, Home Care, Instant Food yang memiliki nilai support 14,1\% dan confidence 100\% serta produk kombinasi. Kombinasi pembelian produk berupa susu, snack, ice cream memiliki nilai support 14,1\% dan confidence 100\%.
\end{abstract}

Kata kunci: Minimarket, Pandemi, Produk, Asosiasi, Tata letak.

\section{Market Basket Analys for Minimarket Goods in Pandemi Covid-19}

\begin{abstract}
A minimarket requires an analysis to find out consumer buying habits during the Covid- 19 pandemic. This research will later be useful for arranging the layout of goods in the store, determining product promotions, and streamlining product stocks so that sales transactions run smoothly and increase sales results. Market basket analysis method can be used to analyze the relationship between products purchased by consumers as well as to determine consumer buying habits. Research has succeeded in finding a combination of interrelated products that have the highest value of support and confidence in the combination of Basic Food, Home Care, Instant Food products that have a support value of $14.1 \%$ and $100 \%$ confidence and combination products. The combination of purchasing products in the form of milk, snacks, ice cream has a support value of $14.1 \%$ and $100 \%$ confidence.
\end{abstract}

Keywords: Minimarket, Pandemic, Product, Association, Layout.

\section{Pendahuluan}

Pandemik covid 19 menuntut masyarakat menjaga jarak sosial untuk mengurangi penyebarannya[1]. Ditinjau dari ekonomi sampai ke kebijakan pemerintah terkena dampaknya. Aktifitas bisnis mengalami penurunan[2]. Sedangkan pemerintahan berdampak pada arah perencanaan pembangunan di Indonesia juga banyak mengalami perubahan[3]. Usaha ritel di Indonesia mengalami penurunan consumer good sebesar $6 \%$ karena penerapan PSBB[4]. Penerapan peraturan tersebut ikut berdapak pada pasar-pasar tradisional[5]. Terdapat dampak penurunan $0,5 \%$ sampai $0,8 \%$ pada konsumsi rumah tangga. Penurunan omset UMKM usaha menengah sebesar $0,07 \%[6]$.

Ritel merupakan bagian dari sektor perdagangan yang mengalami perkembangan yang sangat cepat, hal ini bisa dilihat dari semakin maraknya jumlah gerai ritel di Indonesia. Terdapat 23.000 lebih ritel modern di Indonesia dan sekitar 14.000 diantaranya adalah minimarket[7]. Banyak masyarakat yang memilih berbelanja di minimarket dikarenakan kemudahan memilih produk yang diinginkan, harga produk yang pasti, suasana toko yang aman dan nyaman serta dapat menghemat waktu dan tenaga karena dekat dengan lokasi tempat tinggal masyarakat[8]. Sistem pembayaran di minimarket terkomputerisasi sehingga masyarakat bisa melakukan pembayaran non tunai. Usaha ritel juga sudah banyak yang mulai menggunakan platform online[9]. Barang yang yang dijual diminimarket tidak jauh berbeda dengan barang yang dijual di toko kelontong pada umumnya hanya saja minimarket telah menerapkan konsep swalayan yang mana pembeli mengambil sendiri barang yang di inginkan di rak kemudian membawanya ke meja kasir untuk membayar[10].

Minimarket secara umum yang menjual produk kebutuhan sehari-hari masyarakat seperti bahan pokok, perlengkapan rumah tangga, obat-obatan dan lain sebagainya. Semakin maraknya pertumbuhan minimarket 
maka semakin banyak pesaing dalam mendapatkan pelanggan. Lalu lintas web pada industry e-commerce mengalami peningkatan lebih dari $50 \%$ di masa pandemic covid 19[11]. Untuk itu, membutuhkan analisis yang dapat mengetahui pola pembelian konsumen. Hasil penelitian dapat digunakan sebagai acuan untuk merubah tata letak barang pada rak agar saling berdekatan sesuai pola pembelian konsumen. Hal tersebut mempermudah konsumen dalam berbelanja serta menimbulkan efek impulse buying yaitu pembelian yang tidak terencana oleh pembeli. Meningkatnya efek impulse buying juga akan meningkatkan penjualan barang. Hasil penelitian juga dapat mengetahui produk apa saja yang paling sering dibeli konsumen sehingga dapat mengefisiensikan persediaan barang. Untuk menganalisis kebiasaan konsumen dalam membeli barang maka dibutuhkan data transaksi penjualan yang nantinya akan diolah menggunakan metode data mining yakni metode market basket analisis. Market basket analysis merupakan metode analisis terhadap kebiasaan konsumen dalam berbelanja dengan cara menemukan keterkaitan dan hubungan di antara berbagai macam produk yang dimasukkan konsumen ke dalam keranjang belanjaannya[12].

\section{MEtodoloGI}

\section{A. Data Mining}

Data mining berhubungan dengan penemuan suatu informasi dan pola yang tidak diketahui sebelumnya, ditemukannya pola-pola tersebut dapat membantu pihak yang berkepentingan mengambil keputusan[13]. Data mining merupakan bagian dari knowledge discovery in database (KDD). Tahapan data mining sebagai berikut:

1) Data Cleaning: merupakan proses menghilangkan outlier dan data yang tidak konsisten.

2) Data Integration: merupakan penggabungan data dari banyak database ke dalam satu basis data baru.

3) Data Selection: menyeleksi data yang benar-benar dibutuhkan untuk di telaah.

4) Data Transformation: merubah data ke dalam format yang sesuai untuk diproses dalam data mining.

5) Proses Mining: proses utama untuk mendapatkan pengetahuan baru dari data yang tersembunyi.

6) Pattern Evaluation: menelaah informasi yang dapat digunakan untuk membuat keputusan.

7) Presentasi pengetahuan: visualisasi pengetahuan yang diperoleh dari data mining.

\section{B. Market Basket Analys}

Market Basket Analys adalah suatu kajian terhadap perilaku konsumen[17] secara mendalam dalam melakukan pembelian dengan mencari keterkaitan antar barang yang dibeli untuk mengetahui kebiasaan konsumen dalam berbelanja[14][15][16]. Metode ini dapat membantu retailer untuk mengambil keputusan[18].

\section{Asosiation Rules}

Association rule atau analisis asosiasi adalah teknik data mining untuk menemukan pola yang berkaitan didalam suatu kombinasi item. [19]. Contoh pola asosiasi dari analisis di suatu minimarket dapat diketahui seberapa besar kemungkinan terbelinya minuman dan makanan secara bersamaan.

\section{Algoritma Apriori}

Algoritma apriori adalah suatu algoritma yang paling banyak digunakan dalam menemukan aturan asosiasi, algoritma ini dipilih karena kemudahan dalam proses penerapannya serta visualisasi data yang mudah dipahami. [20] Ada 2 proses utama yang dilakukan dalam algoritma apriori yaitu sebagai berikut:

1) Menganalisis pola frekuensi tinggi melalui pencarian kombinasi item yang memenuhi syarat minimum dari nilai support dalam database. Nilai support sebuah item diperoleh dengan memakai rumus berikut:

$$
\operatorname{Support}(A)=\frac{\text { Jumlah transaksi mengandung A }}{\text { Total transaksi }}
$$

Sedangkan nilai support dari 2 item diperoleh dari rumus berikut:

$$
\text { Support }(A \cap B)=\frac{\text { Jumlah transaksi mengandung A dan B }}{\text { Total transaksi }}
$$

2) Mencari aturan asosiatif yang memenuhi syarat nilai minimum confidence. Setelah semua pola frekuensi tinggi ditemukan, barulah dicari aturan assosiatif yang memenuhi syarat minimum untuk confidence dengan menghitung confidence aturan asosiasi " jika A maka B “. Nilai confidence dari aturan “ jika A maka B “ diperoleh dari rumus berikut :

$$
\mathrm{P}(B / A)=\frac{\text { Jumlah transaksi mengandung A dan } \mathrm{B}}{\text { Jumlah Transaksi mengandung A }}
$$

\section{HASIL DAN PEMBAHASAN}

Pada tahap ini membahas mengenai pengolahan data transaksi penjualan yang diperoleh dari Minimarket. Data diolah menggunakan metode market basket analys yaitu algoritma apriori yang hasilnya nanti akan digunakan untuk mengatur tata letak produk ditoko berdasarkan pola pembelian konsumen dan mengefesiensikan persediaan produk. Metode tersebut digunakan untuk mencari seberapa besar keterkaitan antar produk berdasarkan nilai support dan confidence yang telah ditetapkan. Berikut adalah tahap-tahap pencarian asosiasi produk menggunakan algoritma apriori.

\section{A. Data Transaksi Penjualan}

Data transaksi penjualan yang telah dikumpulkan kemudian dipilih dan diseleksi hingga menghasilkan 99 transaksi penjualan Produk yang saling berkaitan. Kemudian dikelompokkan berdasarkan jenis produk.

Tabel 1. Jenis Produk 
TABEL I

PENGelompoKan JENIS DATA

\begin{tabular}{|c|c|c|}
\hline No & $\begin{array}{l}\text { Jenis } \\
\text { Produk }\end{array}$ & Nama Produk \\
\hline 1 & $\begin{array}{l}\text { BreakFast } \\
\text { Food }\end{array}$ & $\begin{array}{l}\text { TB Chocolate Bun, TB Chocolate } \\
\text { Single Bun 55g, TB Sandwich Kacang, } \\
\text { Super Buryam 22gr, TB Stik Abon } \\
\text { Ayam }\end{array}$ \\
\hline 2 & Susu & $\begin{array}{l}\text { Indomilk UHT Chocolate Kids, } \\
\text { Indomilk UHT Strawberry } 125 \mathrm{ml} \text {, Bear } \\
\text { Brand RTD Milk } 189 \mathrm{ml} \text {, Ultra Mimi } \\
\text { Strawberry } 125 \mathrm{ml}\end{array}$ \\
\hline 3 & Minuman & $\begin{array}{l}\text { Good Day Capucino } 250 \mathrm{ml} \text {, Mindy } \\
\text { 600ml, Sanford } 1500 \mathrm{ml} \text {, Ichitan Thai } \\
\text { Milk Tea } 310 \mathrm{ml} \text {, Ichi Ocha Teh Melati } \\
\text { 350ml, Pocari Sweat } 330 \mathrm{ml} \text {, }\end{array}$ \\
\hline 4 & Basic Food & $\begin{array}{l}\text { Sariwangi Asli } 50 \text { 's, Teh Seduh } \\
\text { Prendjak 50gr, Gula Cap Matahari, } \\
\text { Sunco Mnyk Grg 2lt, Telur, Sunco } \\
\text { Mnyk Grg 1lt, }\end{array}$ \\
\hline 5 & Snack & $\begin{array}{l}\text { Biskuat Energi Coklat 172,8gr, Gery } \\
\text { Chocolatos Dark 16gr, Biskuat Coklat } \\
\text { 10gr, Tango Walut, Oreo Strawberry } \\
\text { 29,4gr, French Fries Prem } 75 \mathrm{~g}\end{array}$ \\
\hline 6 & Ice Cream & Paddle Pop Trico, Aice 2 Colors Stick \\
\hline 7 & Health Care & $\begin{array}{l}\text { OSKADON 50X4'S, Sido M Tolak } \\
\text { Angin Cair, Bodrex isi 10, Ultraflu } \\
\text { Tablet 4s, Cap Lang Minyak telon 15ml, } \\
\text { Fresh Care Strong 10ml }\end{array}$ \\
\hline 8 & Home Care & $\begin{array}{l}\text { Sunlight } 111 \mathrm{ml} \text { reff Lime, Daia Violet } \\
\text { 900g, Sikat Baju Plastik Segi, Rinso } \\
\text { Cair Molto } 800 \mathrm{ml} \text {, Jolly Top Up Tissue }\end{array}$ \\
\hline 9 & Instan Food & $\begin{array}{l}\text { Kapal Tanker 35g, Indomie Goreng } \\
\text { Spesial, Indomie Goreng Ayam Geprek } \\
\text { 85g, Pop Mie Ayam, Sedaap Mie White } \\
\text { Curry, Sedaap Mie Cup, Mie Sedaap } \\
\text { Kari Special, Pop Mie Kari Ayam }\end{array}$ \\
\hline 10 & Baking Needs & $\begin{array}{l}\text { Kraft keju Chedar } 165 \text { gr, Rose Brand } \\
\text { Tepung Beras, Tepung Terigu Segitiga } \\
\text { Biru } 1 \mathrm{~kg} \text {, Tulip Tepung Terigu } 1 \mathrm{~kg}\end{array}$ \\
\hline 11 & Bumbu & $\begin{array}{l}\text { Masako ayam 6's 11g, Bango Kecap } \\
\text { Manis } 275 \mathrm{ml} \text { Btl, } \\
\text { Jawara Hot Saus Sambal }\end{array}$ \\
\hline 12 & Body Care & $\begin{array}{l}\text { Lux Soap 85g Green Fresh Splash, } \\
\text { Lifeboy Total } 1036\end{array}$ \\
\hline 13 & Hair Care & $\begin{array}{l}\text { Pantene Shp 70ml Hairfall AT, Emeron } \\
\text { Shp 170ml Soft \& Smooth }\end{array}$ \\
\hline 14 & Oral Care & $\begin{array}{l}\text { Formula Proteksi } 75 \mathrm{~g} \text {, Pepsodent PG } \\
\text { White 120, Formula SG Silver Pro } \\
\text { Trendy-S, Formula SGF Triple Action, }\end{array}$ \\
\hline 15 & Kosmetik & Mutiara Parfum Non Alkohol Spray \\
\hline 16 & $\begin{array}{l}\text { Insect Killer / } \\
\text { Pembasmi } \\
\text { serangga }\end{array}$ & Baygon Jumbo, Autan Kids \\
\hline 17 & Alat Tulis & $\begin{array}{l}\text { Buku Tulis SIDU 38L, Pennsil 2B, Pena } \\
\text { Standar Tecno Hitam }\end{array}$ \\
\hline
\end{tabular}

\section{B. Analisa Pola Frekuensi Tinggi}

Pada tahap ini dilakukan pencarian kombinasi itemset produk yang memenuhi syarat nilai minimum support yang telah ditetapkan. Minimum support pada penelitian ini adalah $10 \%$.
TABEL III

ITEMSET-1

\begin{tabular}{|l|l|l|l|}
\hline No & Jenis Produk & Frekuensi & Support \\
\hline 1 & BreakFast Food & 20 & $20,2 \%$ \\
\hline 2 & Susu & 24 & $24,2 \%$ \\
\hline 3 & Minuman & 21 & $21,2 \%$ \\
\hline 4 & Basic Food & 19 & $19,2 \%$ \\
\hline 5 & Snack & 20 & $20,2 \%$ \\
\hline 6 & Ice Cream & 18 & $18,2 \%$ \\
\hline 7 & Health Care & 16 & $16,2 \%$ \\
\hline 8 & Home Care & 19 & $19,2 \%$ \\
\hline 9 & Instan Food & 18 & $18,2 \%$ \\
\hline 10 & Baking Needs & 11 & $11,1 \%$ \\
\hline 11 & Bumbu & 17 & $17,2 \%$ \\
\hline 12 & Body Care & 17 & $17,2 \%$ \\
\hline 13 & Hair Care & 14 & $14,1 \%$ \\
\hline 14 & Oral Care & 17 & $17,2 \%$ \\
\hline 15 & Kosmetik & 14 & $14,1 \%$ \\
\hline 16 & Insect Killer & 11 & $11,1 \%$ \\
\hline 17 & Alat Tulis & 19 & $19,2 \%$ \\
\hline
\end{tabular}

Kemudian hasil pada itemset 2 adalah sebagai berikut:

TABEL IIIII

ITEMSET-2

\begin{tabular}{|c|l|c|l|}
\hline No & \multicolumn{1}{|c|}{ Jenis Produk } & Frekuensi & Support \\
\hline 1 & BreakFast Food, Susu & 10 & $10,1 \%$ \\
\hline 2 & BreakFast Food, Minuman & 13 & $13,1 \%$ \\
\hline 3 & BreakFast Food, Snack & 14 & $14,1 \%$ \\
\hline 4 & Susu, Minuman & 10 & $10,1 \%$ \\
\hline 5 & Susu, Snack & 14 & $14,1 \%$ \\
\hline 6 & Susu, Ice Cream & 14 & $14,1 \%$ \\
\hline 7 & Minuman, Snack & 13 & $13,1 \%$ \\
\hline 8 & Basic Food, Home Care & 14 & $14,1 \%$ \\
\hline 9 & Basic Food, Instan Food & 14 & $14,1 \%$ \\
\hline 10 & Snack, Ice Cream & 14 & $14,1 \%$ \\
\hline 11 & Home Care, Instan Food & 14 & $14,1 \%$ \\
\hline 12 & Body Care, Hair Care & 12 & $12,1 \%$ \\
\hline
\end{tabular}

Kemudian hasil pada itemset 3 adalah sebagai berikut:

\section{TABEL IVV}

ITEMSET-3

\begin{tabular}{|c|l|c|c|}
\hline No & \multicolumn{1}{|c|}{ Jenis Produk } & Frekuensi & Support \\
\hline 1 & BreakFast Food, Minuman, Snack & 13 & $13,1 \%$ \\
\hline 2 & Susu, Snack, Ice Cream & 14 & $14,1 \%$ \\
\hline 3 & Basic Food, Home Care, Instan Food & 14 & $14,1 \%$ \\
\hline
\end{tabular}

\section{Pembentukan Aturan Asosiatif}

Setelah semua frekuensi tinggi ditemukan, langkah selanjutnya yang dilakukan adalah mencari aturan asosiasi $\mathrm{A} \rightarrow \mathrm{B}$ yang memenuhi syarat nilai minimum confidence. Syarat nilai minimum confidence yang peneliti tetapkan adalah $100 \%$.

TABEL V

ATURAN ASOSIASI

\begin{tabular}{|l|l|l|l|}
\hline No & Rules & Support & Confidence \\
\hline 1 & $\begin{array}{l}\text { Jika membeli produk Minuman } \\
\text { dan Snack maka akan membeli } \\
\text { produk BreakFast Food. }\end{array}$ & $13,1 \%$ & $100 \%$ \\
\hline 2 & $\begin{array}{l}\text { Jika membeli produk Minuman } \\
\text { dan BreakFast Food maka akan } \\
\text { membeli produk Snack. }\end{array}$ & $13,1 \%$ & $100 \%$ \\
\hline 3 & $\begin{array}{l}\text { Jika membeli produk Snack dan } \\
\text { Ice Cream maka akan membeli } \\
\text { produk Susu. }\end{array}$ & $14,1 \%$ & $100 \%$ \\
\hline 4 & $\begin{array}{l}\text { Jika membeli produk Susu dan Ice } \\
\text { Cream maka akan membeli } \\
\text { produk Snack. }\end{array}$ & $14,1 \%$ & $100 \%$ \\
\hline
\end{tabular}




\begin{tabular}{|l|l|l|l|}
\hline No & Rules & Support & Confidence \\
\hline 5 & $\begin{array}{l}\text { Jika membeli produk Susu dan } \\
\text { Snack maka akan membeli produk } \\
\text { Ice Cream. }\end{array}$ & $14,1 \%$ & $100 \%$ \\
\hline 6 & $\begin{array}{l}\text { Jika membeli produk Basic Food } \\
\text { dan Home Care maka akan } \\
\text { membeli produk Instan Food. }\end{array}$ & $14,1 \%$ & $100 \%$ \\
\hline 7 & $\begin{array}{l}\text { Jika membeli produk Basic Food } \\
\text { dan Instan Food maka membeli } \\
\text { produk Home Care. }\end{array}$ & $14,1 \%$ & $100 \%$ \\
\hline 8 & $\begin{array}{l}\text { Jika membeli produk Home Care } \\
\text { dan Instan Food maka membeli } \\
\text { produk Basic Food. }\end{array}$ & $14,1 \%$ & $100 \%$ \\
\hline
\end{tabular}

Untuk membuktikan pola kombinasi itemset yang didapat dari perhitungan manual benar maka dilakukan pengujian menggunakan software Tanagra. Hasil pengujian Tanagra pada itemset-2 dapat dilihat pada gambar berikut:

\begin{tabular}{|c|c|c|}
\hline \multicolumn{3}{|c|}{ ITEMSETS [ 112 itemsets loaded] } \\
\hline $\mathbb{N}^{2}$ & Descipion & Surport \\
\hline 1 & Hair_Care /Body_Crie & 12,1 \\
\hline 2 & Instan_Food $/$ Easic_Food & 14,1 \\
\hline 3 & Instan_Food/ Home_Care & 14.1 \\
\hline 4 & Basic_Food M Home_Cae & 14,1 \\
\hline 5 & lec_ciem / S Srack & 14,1 \\
\hline 6 & Icę_reemm / Susu & 14,1 \\
\hline 7 & Breakklast_food/M Snack & 14,1 \\
\hline 8 & Breaklas_fFood/Minuman & 13.1 \\
\hline 9 & Breatrost Food ^ Susu & 10,1 \\
\hline 10 & Snack $/$ Minumanin & 13,1 \\
\hline 11 & Snack $/$ Susu & 14,1 \\
\hline 12 & Miruman $\wedge$ Susu & 10.1 \\
\hline
\end{tabular}

Gambar 1. Hasil Itemset-2

Hasil pengujian Tanagra pada itemset-3 dapat dilihat pada gambar berikut:

\begin{tabular}{|c|c|}
\hline & \\
\hline $\mathbb{N}^{1}$ Descipiption & Suppoot \\
\hline 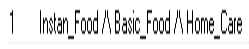 & 14,1 \\
\hline 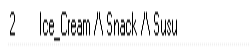 & 14,1 \\
\hline 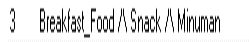 & 13,1 \\
\hline
\end{tabular}

Gambar 2. Hasil Itemset-3

Hasil aturan asosiasi dari pengujian Tanagra dapat dilihat pada gambar berikut:

RULES

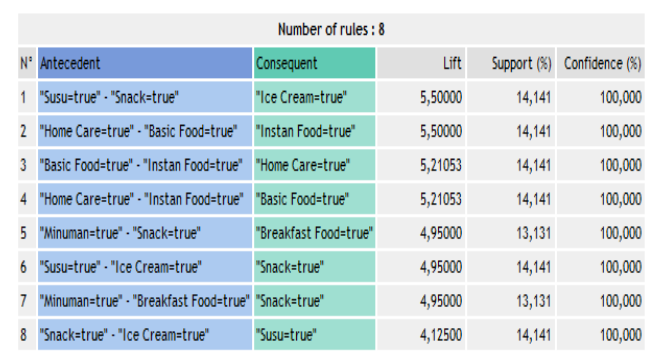

Gambar 3. Asosiation rules

Hasil yang diperoleh dari pengujian asosiation rules menggunakan software tanagra menunjukkan hasil perhitungan yang sama dengan perhitungan manual dengan penetapan syarat nilai minimum support $10 \%$ dan confidence $100 \%$ menghasilkan 8 rules yaitu sebagai berikut:

1) Jika membeli produk Susu dan Snack maka $100 \%$ akan membeli produk Ice Cream.

2) Jika membeli produk Home care dan Basic Food maka 100\% akan membeli produk Instan Food.

3) Jika membeli produk Basic Food dan Instan Food maka 100\% akan membeli produk Home Care.

4) Jika membeli produk Home Care dan Instan Food maka $100 \%$ akan membeli produk Basic food.

5) Jika membeli produk Minuman dan Snack maka 100\% akan membeli produk BreakFast food.

6) Jika membeli produk Susu dan Ice Cream maka $100 \%$ akan membeli produk Snack.

7) Jika membeli produk Minuman dan BreakFast Food maka $100 \%$ akan membeli produk Snack.

8) Jika membeli produk Snack dan Ice Cream maka $100 \%$ akan membeli produk Susu.

\section{KESIMPULAN}

Setelah semua perhitungan dan pengujian yang dilakukan oleh peneliti selesai maka dapat diambil kesimpulan sebagai berikut:

1. Berdasarkan hasil perhitungan menggunakan algoritma asosiation rules didapatkan hasil kombinasi item dengan nilai support dan confidence tertinggi pada kombinasi produk Home Care, Basic Food, Instant Food dengan nilai support $14,1 \%$ dan confidence $100 \%$ dan kombinasi produk Susu, Snack, Ice cream dengan nilai support $14,1 \%$ dan confidence 100\%. Dapat disimpulkan kombinasi produk yang paling sering dibeli konsumen secara bersamaan adalah produk Home Care, Basic Food, Instant Food dan kombinasi produk Susu, Snack, Ice cream.

2. Data transaksi penjualan diolah menggunakan metode market basket analys kemudian diperoleh kombinasi item yang paling sering dibeli secara bersamaan, sehingga dapat digunakan pihak minimarket untuk menentukan jumlah persediaan barang, menentukan tata letak produk ditoko agar saling berdekatan dan mudah dijangkau oleh konsumen sesuai pola pembelian konsumen.

\section{UCAPAN TERIMA KASIH}

Terima kasih dan penghargaan kepada LPPM Universitas Putera Batam yang telah membantu dalam fasilitas laboratorium dan pustaka hingga dapat terselesainya penelitian.

\section{DAFTAR PUSTAKA}

[1] J. Yawney and S. A. Gadsden, "A Study of the COVID-19 Impacts on the Canadian Population," IEEE Access, vol. 8, pp. 128240-128249, 2020.

[2] A. D. Kusumastuti, "Pengaruh Pandemi Covid-19 Terhadap Eksistensi Bisnis Umkm Dalam Mempertahankan Business Continuity Management (Bcm)," J. Adm. Bisnis Fisipol Unmul, vol. 8, no. 3, pp. 224-232, 2020.

[3] Muhyiddin, "Covid-19, New Normal, dan Perencanaan 
Pembangunan di Indonesia," J. Perenc. Pembang. Indones. J. Dev. Plan., vol. 4, no. 2, pp. 240-252, 2020.

[4] P. Widyastuti, "Analisis Keputusan Pembelian: Fenomena Panic Buying Dan Service Convenience ( Studi Pada Grocery Store Di Dki Jakarta )," Proceeding SENDIU, vol. 1, no. 6, pp. 583-591, 2020.

[5] A. Bayu and M. Kamim, "Wabah Virus Korona Dan Momentum Evaluasi Rezim Ketahanan Pangan Di Indonesia ( Covid-19 Pandemic and Momentum of Food Security Evaluation in Indonesia )," J. Kependud. Indones., vol. 2902, pp. 87-92, 2020.

[6] A. Amri, "Dampak Covid-19 Terhadap UMKM di Indonesia," J. Brand, vol. 2, no. 1, pp. 147-153, 2020.

[7] H. Andika and S. W. Hati, "Analisis perbandingan kepuasan pelanggan antara minimarket indomaret dengan alfamart di kota batam," vol. 6, no. 2, pp. 119-134, 2018.

[8] R. D. Bekti, N. Pratiwi, M. T. Jatipaningrum, and D. Auliana, "Analisis Pengaruh Lokasi Dan Karakteristik Konsumen Dalam Memilih Minimarket Dengan Metode Regresi Logistik Dan Cart," Media Stat., vol. 10, no. 2, p. 119, 2017.

[9] T. Taufik and E. A. Ayuningtyas, "Dampak Pandemi Covid 19 Terhadap Bisnis Dan Eksistensi Platform Online," J. Pengemb. Wiraswasta, vol. 22, no. 01, p. 21, 2020.

[10] E. Elisa, "Market Basket Analysis Pada Mini Market Ayu Dengan Algoritma Apriori," J. RESTI (Rekayasa Sist. dan Teknol. Informasi), vol. 2, no. 2, pp. 472-478, 2018.

[11] G. Surya, P. Gede, and S. Cipta, "Komparasi Metode AHPSAW dan AHP-WP pada SPK Penentuan E-Commerce Terbaik di Indonesia Comparison of AHP-SAW and AHP-WP Methods on DSS to Determine the Best E-Commerce in Indonesia," vol. 08, no. 4, pp. 346-356, 2020.
R. Muzawi, Tashid, and M. Nasution, "Sistem Monitoring Ketersediaan Bahan Baku Cor Beton Menggunakan Metode Market Basket Analysis," J. Teknol. Dan Sist. Inf. Bisnis, vol. 1, no. 1, 2019.

[13] H. Santoso, I. P. Hariyadi, and Prayitno, "Data Mining Analisa Pola Pembelian Produk Dengan Menggunakan Metode Algoritma Apriori," Tek. Inform., no. 1, pp. 19-24, 2016.

[14] A. N. Sagin and B. Ayvaz, "Determination of Association Rules with Market Basket Analysis: Application in the Retail Sector," Southeast Eur. J. Soft Comput., vol. 7, no. 1, 2018.

[15] N. Isa, N. A. Kamaruzzaman, M. A. Ramlan, N. Mohamed, and M. Puteh, "Market Basket Analysis of Customer Buying Patterns at Corm Café," Int. J. Eng. Technol., vol. 7, no. October, pp. 119-123, 2018.

[16] I. A., O. U., O. T., F. T., and A. A., "Automated Market Basket Analysis System," Int. J. Comput. Appl., vol. 180, no. 39, pp. 44-51, 2018.

[17] I. Surjandari and A. C. Seruni, "Design of Product Placement Layout in Retail Shop Using Market Basket Analysis,' MAKARA Technol. Ser., vol. 9, no. 2, pp. 43-47, 2010.

[18] M. Kaur and S. Kang, "Market Basket Analysis: Identify the Changing Trends of Market Data Using Association Rule Mining," Procedia Comput. Sci., vol. 85, no. Cms, pp. 78-85, 2016.

[19] N. A. Hasibuan et al., "Implementasi Data Mining Untuk Pengaturan Layout," vol. 4, no. 4, pp. 6-11, 2017.

[20] A. Madan Mirajkar, A. P. Sankpal, P. S. Koli, R. A. Patil, A. R. Pradnyavant, and J. J. Magdum, "Data Mining Based Store Layout Architecture for Supermarket," Int. Res. J. Eng. Technol., pp. 2395-56, 2016. 